\title{
FILTERING SPAM EMAIL MENGGUNAKAN METODE NAIVE BAYES
}

\author{
Aria Wibisono $^{1)}$, Sampurna Dadi Rizkiono ${ }^{2)}$, Agus Wantoro ${ }^{3)}$ \\ Program Studi Informatika, Universitas Teknokrat Indonesia \\ Jl. H. ZA. Pagar Alam No. 9-11, Labuhan Ratu, Bandar lampung \\ Email : ariawibisono7@gmail.com ${ }^{1}$,sampoerna.go@gmail.com²,aguswantoro@teknokrat.ac.id ${ }^{3}$
}

\begin{abstract}
Abstrak
Spam adalah email yang tidak diminta yang berisi promosi produk, pornografi, virus dan contentcontent yang tidak penting, yang dikirim ke banyak orang. Masalah spam dapat diatasi dengan adanya aplikasi filtering email, yaitu aplikasi yang secara otomatis mendeteksi sebuah email, apakah email tersebut spam atau bukan. Naive Bayes merupakan salah satu metode klasifikasi sederhana yang dapat digunakan untuk mengelompokkan data berdasarkan kriteria tertentu. Metode ini memanfaatkan teorema probabilitas yaitu mencari peluang terbaik, dengan memprediksi probabilitas di masa depan berdasarkan informasi di masa sebelumnya. Tujuan utama penelitian ini adalah mengkaji penerapan metode Naive Bayes untuk menentukan email spam dan email ham. Hasil pengujian aplikasi terhadap 5 email yang terdiri dari 2 email spam dan 3 email ham menunjukkan bahwa algoritma naive bayes mempu mengklasifikasikan email dengan akurasi $60 \%$.
\end{abstract}

Kata Kunci : spam, naive bayes, klasifikasi, email.

\section{Pendahuluan}

Penggunaan internet telah menjadi kebutuhan yang penting dalam kehidupan berkomunikasi. Dari sekian banyak fasilitas di internet, salah satunya adalah surat elektronik atau yang lebih dikenal sebagai email. Electronic mail (email) merupakan media komunikasi di internet seperti untuk berdiskusi (maillist), transfer informasi berupa file (mail attachment) bahkan dapat digunakan untuk media iklan suatu perusahaan. Mengingat fasilitas email yang murah dan kemudahan untuk mengirimkan ke berapapun jumlah penerimanya maka beberapa pihak tertentu memanfaatkannya dengan mengirimkan email berisi promosi produk atau jasa, pornografi, virus, dan content-content yang tidakpenting ke ribuan pengguna email. Email-email inilah yang biasanya disebut dengan spam. Untuk mengatasi masalah ini diperlukan suatu filter[1], salah satunya adalah klasifikasi, yang dapat memisahkan spam e-mail dan bukan spam e-mail [2]. Terdapat beberapa metode yang dapat digunakan dalam klasifikasi spam e-mail seperti Decision Tree, KNearest Neighbor (KNN), Naïve Bayes, ID3 dan C4.5. Dari metode-metode tersebut, naive bayes merupakan metode statistik yang sederhana dan memiliki akurasi yang baik serta error rate yang minimum dalam proses pengklasifikasian [3].

Naïve bayes disebut juga multinomial naïve bayes merupakan metode klasifikasi yang memanfaatkan metode probabilitas dan statistik. Metode ini merupakan model penyederhanaan dari algoritma bayes yang cocok dalam pengklasifikasian teks atau dokumen. Dalam klasifikasi menggunakan naïve bayes, nilai kategori dari suatu dokumen akan ditentukan berdasarkan fitur/kata yang muncul dalam dokumen yang akan diklasifikasikan. Masalah tersebut dapat diatasi dengan adanya aplikasi email filtering [4][5].Tetapi meskipun berbagai perangkat lunak email filtering banyak tersedia,masalah spam juga semakin berkembang, sehingga melahirkan beberapa metode email filtering. Salah satu metode email filtering yang paling populer yaitu metode Bayes (Bayesian filtering) [6]. Metode ini memanfaatkan teorema probabilitas yaitu teorema Bayes, dengan memprediksi probabilitas di masa depan berdasarkan informasi di masa sebelumnya.

Oleh karena itu penulis mencoba mengkaji penerapan metode Bayes pada proses email filtering dan kemudian menganalisis tingkat akurasi dari Bayesian filtering tersebut. Dengan melakukan penelitian judul "Filtering Spam E-mail menggunakan metode Nä̈ve Bayes".

\section{Landasan Teori}

\subsection{Klasifikasi Teks}

Kategorisasi teks (atau Klasifikasi teks) adalah suatu proses yang mengelompokan suatu teks ke dalam suatu kategori tertentu [7][8]. Dalam text mining, klasifikasi mengacu kepada aktifitas menganalisis atau mempelajari himpunan dokumen teks pre-classified untuk memperoleh suatu model atau fungsi yang dapat digunakan untuk mengelompokkan dokumen teks lain yang belum diketahui class-nya ke dalam satu atau lebih class pre-defined tersebut.

Dokumen yang digunakan untuk pembelajaran dinamakan contoh (sample atau training dataset) yang dideskripsikan oleh himpunan atribut atau variabel. Klasifikasi termasuk pembelajaran jenis supervised learning. Jenis lain adalah unsupervised learning atau 
dikenal sebagai clustering. Pada supervised learning, data latihan mengandung pasangan data input (biasanya vektor) dan output yang diharapkan, sedangkan pada unsupervised learning belum ditentukan target output yang harus diperoleh.

Proses klasifikasi teks dapat dibagi ke dalam dua fase, yaitu fase information retrieval (IR) yakni untuk mendapatkan data numerik dari dokumen teks dan fase klasifikasi utama yakni dimana suatu algoritma memroses data numerik di atas untuk memutuskan ke kategori mana teks baru (bukan contoh) ditempatkan [9].

\subsection{Pengertian Corpus}

Corpus didefinisikan sebagai kumpulan sistematis teks alami termasuk bahasa lisan maupun tertulis dimana struktur dan isi dari corpus mengikuti prinsip-prinsip linguistik tertentu (Nesselhauf, 2005). Corpus yang digunakan dalam penelitian ini adalah corpus Lingspam.

\subsection{Spam}

Spam atau junk mail adalah penyalahgunaan dalam pengiriman berita elektronik untuk menampilkan berita iklan dan keperluan lainnya yang mengakibatkan ketidaknyamanan bagi para pengguna web [2]. Menurut Rahardjo (2006), spam adalah unsolicited email (email yang tidak diminta) yang dikirim ke banyak orang.

Berikut ini definisi dari spam menurut Lambert (2003).

1. Isi atau konten dari email tidak relevan dengan minat penerima.

2. Penerima tidak dapat menolak datangnya email yang tidak diminta tersebut dengan cara-cara lazim.

3. Dari sisi penerima, pengiriman dan penerimaan pesan tersebut memberikan keuntungan bagi pengirimnya.

Bentuk berita spam yang umum dikenal meliputi: spam pos-el, spam pesan instan, spam usenet news-group, spam mesin pencari informasi web (web search engine spam), spam blog, spam berita pada telepon genggam, spam forum internet, dan lain lain. Spam ini biasanya datang bertubi-tubi tanpa diminta dan sering kali tidak dikehendaki oleh penerimanya.

Menurut Rahardjo (2006), spam terjadi akibat murahnya biaya untuk mengirimkan spam. Biaya untuk mengirimkan satu email sama dengan seribu email, atau bahkan satu juta email.

Spam dapat dikategorikan sebagai berikut.

1. Junk mail yaitu email yang dikirimkan secara besar-besaran dari suatu perusahaan bisnis, yang sebenarnya tidak kita inginkan.
2. Non-commercial spam, misalnya surat berantai atau cerita humor yang dikirimkan secara masal tanpa tujuan komersial tertentu.

3. Pornographic spam yaitu email yang dikirimkan secara masal untuk mengirimkan gambar-gambar pornografi.

4. Virus spam yaitu email yang dikirimkan secara massal, dan mengandung virus atau Trojans.

\subsection{Email Filtering}

Email filtering adalah suatu proses yang otomatis akan mendeteksi sebuah email, apakah email tersebut sebuah spam atau bukan (ham email). Beberapa metode yang dapat digunakan untuk email filtering antara lain Keyword filtering, Black listing dan White listing, Signature-Based filtering, Naive Bayesian (statistical) filtering.

Beberapa karakteristik email filtering yaitu.

1. Binary class email filtering hanya mengklasifikasikan email ke dalam kelas spam dan legitimate email.

2. Prediksi email filtering mampu melakukan prediksi kelas dari suatu email.

3. Komputasi mudah mengingat sifat data email yang memiliki dimensi tinggi maka dibutuhkan sebuah email filter yang mampu melakukan komputasi dengan mudah.

4. Learning mampu melakukan learning dari email-email yang sudah ada sebelumnya.

5. Kinerja yang bagus memiliki akurasi yang tinggi, meminimalkan nilai false positive dan mentolerir nilai false negative yang cukup tinggi.

\subsection{Naive Bayes}

Naïve Bayes atau multinomial naïve bayes merupakan metode yang digunakan untuk mengklasifikasikan sekumpulan dokumen. Algoritma ini memanfaatkan metode probabilitas dan statistik yang dikemukakan oleh ilmuwan Inggris Thomas Bayes. Metode NB menempuh dua tahap dalam proses klasifikasi teks, yaitu tahap pelatihan dan tahap pengujian (klasifikasi). Pada tahap pelatihan dilakukan proses analisis terhadap sampel dokumen berupa pemilihan vocabulary, yaitu kata yang mungkin muncul dalam koleksi dokumen sampel yang sedapat mungkin dapat menjadi representasi dokumen. Selanjutnya adalah penentuan probabilitas prior bagi tiap kategori berdasarkan sampel dokumen. Pada tahap klasifikasi ditentukan nilai kategori dari suatu dokumen berdasarkan term yang muncul dalam dokumen yang diklasifikasi. 
Dalam naïve bayes, kemungkinan dokumen $d$ berada di class $C$ dihitung sebagai berikut:

$$
P(c \mid d) \propto P(c) \prod 1 \leq k \leq n d P(t k \mid c)(2.1)
$$

dimana $P(t k \mid C)$ adalah conditional probability dari fitur $t k$ yang terdapat dalam dokumen dari class $C$. Dapat diartikan, $P(t k \mid C)$ adalah ukuran berapa banyak kemunculan fitur $t k$ memberikan kontribusi bahwa $C$ adalah class yang benar. $P(C)$ adalah prior probability dari dokumen yang terdapat di class $C$. Jika fitur dari sebuah dokumen tidak memberikan evidence yang jelas untuk sebuah class dibandingkan dengan class lainnya, maka fitur dengan prior probability tertinggi yang akan dipilih. Token dalam $d(t 1, t 2, \ldots ., t n d)$ merupakan bagian dari vocabulary yang digunakan untuk klasifikasi dan $n d$ adalah jumlah token tersebut dalam $d$.

Tujuan utama dalam klasifikasi teks adalah menemukan best class untuk sebuah dokumen. Best class dalam naïve bayes adalah yang paling mungkin atau maximum a posteriori (MAP) class $C_{\text {map }}$ :

$$
\begin{aligned}
& C_{\text {map }}=\arg \max c \in C \text { Ṕ }(C \mid d)=\arg \max c \in C \\
& \dot{\mathrm{P}}(c) \prod 1 \leq k \leq n d \dot{\mathrm{P}}(t k \mid C)
\end{aligned}
$$

dimana arg max adalah argument maximum dan untuk $P$ ditulis Ṕ karena tidak diketahui nilai sebenarnya dari parameter $P(C)$ dan $P(t k \mid C)$.

Pada Persamaan (2.2), banyak conditional probability yang dikalikan, satu untuk masing-masing posisi $1 \leq k \leq n d$. Hal ini dapat mengakibatkan masalah underflow. Masalah underflow adalah masalah yang muncul pada dokumen yang memiliki jumlah kata yang sangat besar. Hasil perkalian dari nilai-nilai conditional probability dari seluruh kata yang berjumlah sangat besar akan membuat variabel score bernilai sangat kecil. Nilai score yang sangat kecil dapat menimbulkan kesalahan saat dilakukan proses perbandingan. Oleh karena itu, lebih baik untuk melakukan perhitungan dengan menambahkan logaritma probabilitas daripada mengalikan probabilitas. Class dengan nilai probabilitas tertinggi masih yang paling mungkin. Oleh karena itu maksimalisasi yang sebenarnya dilakukan dalam kebanyakan implementasi dari naïve bayes adalah:

$$
\begin{aligned}
& c_{\text {map }}=\arg \max c \in C\left[\log \mathrm{P}(c)+\underset{(2.3)}{\sum 1 \leq k \leq n d}\right. \\
& \log \hat{P}(t k \mid c)]
\end{aligned}
$$

untuk menghitung nilai dari Ṕ ( $C$ ) adalah sebagai berikut:

$$
\dot{\mathrm{P}}=\frac{N_{C}}{\mathrm{~N}}
$$

( $N C$ adalah dokumen yang berada di class $C$ dan $N$ adalah jumlah dokumen) Diperkirakan conditional probability $\mathrm{P}(t \mid C)$ sebagai frekuensi relatif dari fitur $t$ dalam dokumen-dokumen di class $C$ dapat dihitung dengan persamaan:

$$
\dot{\mathrm{P}}(\mathrm{t} \mid \mathrm{c})=\frac{T_{c t}}{\sum_{t^{\prime} \in V^{T}} T_{c t^{\prime}}}
$$

(T $c t$ adalah jumlah kemunculan fitur $t$ dalam training dokumen dari class $C$ ).

Persamaan (2.3) memiliki interpretasi yang sederhana. Setiap kondisi parameter $\log P(t k \mid c)$ adalah bobot yang menunjukkan seberapa baik indikator $t k$ untuk $C$. Demikian pula Ṕ $(c)$ adalah bobot yang menunjukkan frekuensi relatif $c$. Hasil penjumlahan log prior probability dan bobot fitur adalah ukuran tentang berapa banyak kemunculan yang ada untuk dokumen di class $C$ dan Persamaan (2.3) memilih class dengan evidence terbanyak.

Persamaan (2.5) akan menimbulkan masalah baru apabila fitur tidak ditemukan dalam training set. Fitur yang tidak ditemukan menyebabkan masalah pembagian dengan nol (devision by zero). Untuk mengatasi hal tersebut maka digunakan add-one atau Laplace Smoothing, seperti tampak pada Persamaan (2.6).

$\dot{P}(\mathrm{t} \mid \mathrm{C})=\frac{T_{c t}+1}{\sum_{t^{\prime} \in V}\left(T_{c t}^{\prime}+1\right)}=\frac{T_{c t}+1}{\left(\sum_{t^{\prime} \in V^{\prime}} T_{c t}^{\prime}\right)+\mathrm{B}^{\prime}}$

dimana $B=|V|$ adalah jumlah fitur dalam vocabulary.

\subsection{Klasifikasi Teks Menggunakan Naive Bayes}

Di dalam proses klasifikasi menggunakan multinomial naïve bayes, akan dilakukan terlebih dahulu preprocessing e-mail.

\section{Preprocessing}

Tahap pre-processing e-mail dilakukan untuk menghilangkan fitur-fitur yang tidak penting dan membersihkan seluruh dokumen e-mail dari markup tag sehingga saat digunakan akan meningkatkan akurasi dari classifier. Berikut ini merupakan langkahlangkah umum dalam pre-processing e-mail:

1. Tokenisasi

Langkah awal adalah mengekstrak isi dokumen $e$ mail ke dalam bentuk kata/fitur atau lebih dikenal 
dengan nama token. Proses ini dinamakan tokenisasi. Pada tahap ini juga dilakukan case folding, yaitu penyeragaman bentuk huruf dimana seluruh huruf diseragamkan ke bentuk huruf kecil yaitu antara huruf "a" sampai huruf " $z$ " dan juga menghilangkan karakter-karakter tertentu seperti tanda baca dan angka.

2. Eliminasi stopword

Stopwords adalah kata-kata yang memiliki frekuensi kemunculan yang tinggi dalam dokumen namun tidak memiliki nilai informasi yang tinggi. Contoh stopword misalnya kata "the", "and", "a", "of", "in", "is", "this", "that". Dalam penelitian yang dilakukan oleh Silvatt dan Ribeirot (2003), mereka menyimpulkan bahwa penghapusan stopwords memiliki efek yang signifikan untuk meningkatkan akurasi classifier.

3. Lemmatisasi fitur

Proses lemmatisasi (lemmatization) akan mereduksi kata ke dalam bentuk kata dasar atau sering disebut lemma dimana kata dasar (lemma) tersebut memiliki arti dan ditemukan dalam kamus. Misalnya, kata "walked", "walks", dan "walking" jika dilakukan proses lemmatisasi maka lemmanya adalah "walk" (kata "walk" ada di dalam kamus Bahasa Inggris).

\subsection{Klasifikasi Email}

Penggunaan metode naïve bayes terdiri dari dua fase, yaitu fase pelatihan dan fase pengujian. Berikut ini adalah tahap-tahap pada fase pelatihan dan fase pengujian:

a. Fase Pelatihan (training):

Fase pelatihan adalah sebagai berikut:

1. Ekstrak seluruh kata dari seluruh dokumen dalam dokumen latih kemudian buat tabel representasi dokumen latih.

2. Hitung prior probability $P$ class untuk setiap class dengan menggunakan rumus pada persamaan (2.4).

3. Hitung conditional probability dari semua kata dan class dengan menggunakan rumus pada persamaan (2.6).

\section{b. Fase Pengujian (testing):}

Fase pengujian adalah sebagai berikut:

1. Ekstrak seluruh kata dari seluruh dokumen dalam dokumen latih.

2. Hitung bobot (score) dari dokumen $d$ yang termasuk dalam class $C$ dengan menggunakan rumus pada persamaan (2.2).

3. Prediksi class dokumen uji dengan cara memilih class yang memiliki skor terbesar berdasarkan persamaan (2.3).

\section{Metode Penelitian}

Tahapan yang digunakan untuk perhitungan menggunakan algoritma Naive Bayes Classification sebagai berikut:

Tahapan Pelatihan

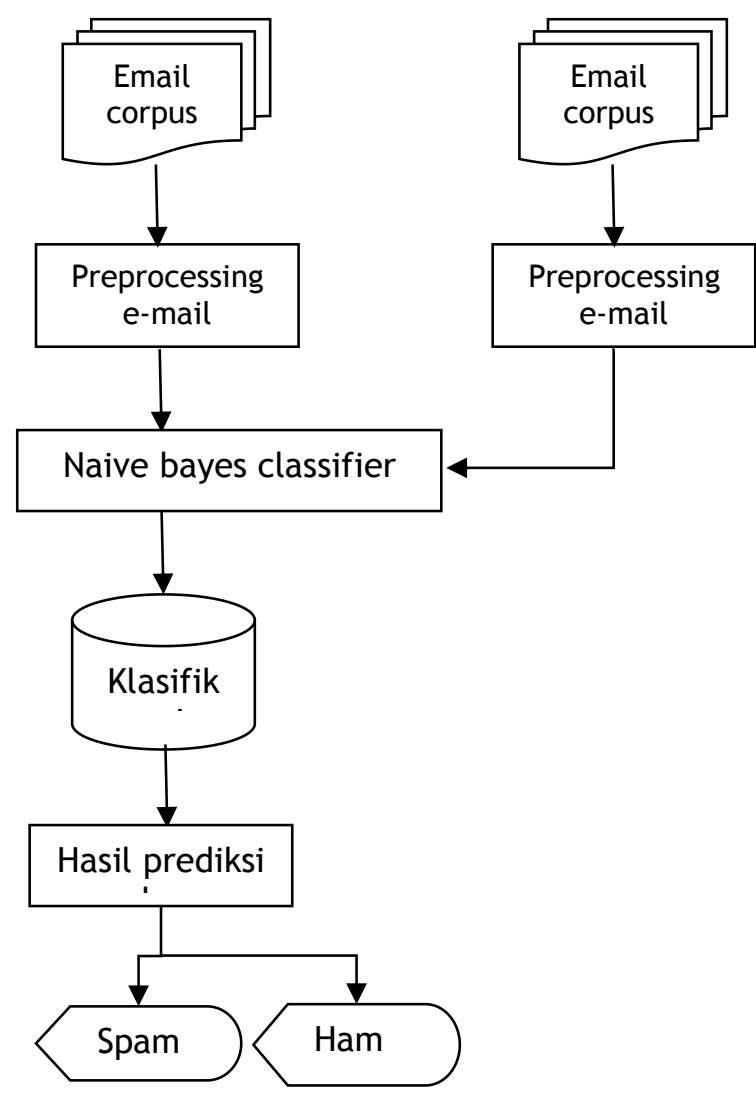

Gambar 3.1 Tahapan Penelitian

\subsection{Corpus}

Corpus Lingspam yang terdiri dari 2893 e-mail yang terdiri dari 2412 ham e-mail (e-mail yang bukan spam) dan 481 spam e-mail yang terbagi dalam 10 part. E-mail yang digunakan dalam tahap pelatihan diambil dari part 2, sedangkan e-mail dari part 1 akan digunakan dalam tahap pengujian, tetapi tidak digunakan semua dikhawatirkan akan memboroskan memori pada saat digunakan dalam aplikasi. Gambar 3.2 merupakan folder dalam corpus Lingspam dan bagian yang digunakan yang berada di dalam folder "lemm_stop" yang berarti sudah dilakukan lemmatisasi dan eliminasi stopwords. Gambar 3.2 merupakancontoh e-mail yang digunakan. 


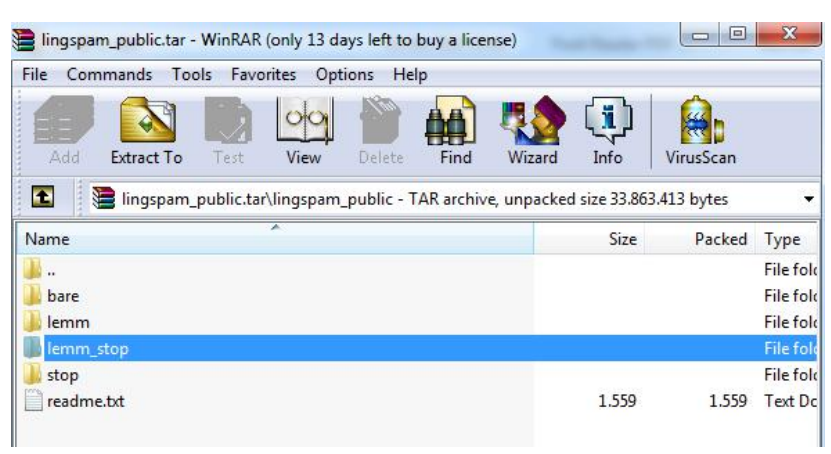

Gambar 3.2 Corpus Lingspam

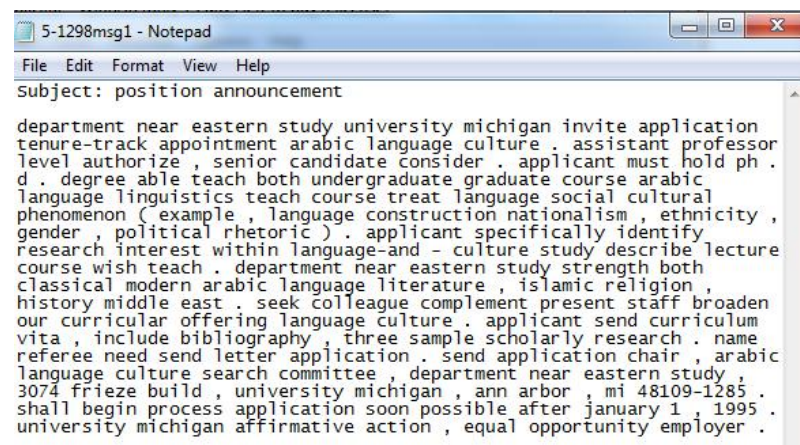

Gambar 3.3 Contoh e-mail ham

\subsection{Prosedur dan Pengumpulan Data}

Pengumpulan data merupakan tahapan persiapan yang harus dilaksanakan terlebih dahulu sebelum dilakukan penelitian [10]. Berikut merupakan aktivitas yang dilaksanakan dalam pengumpulan sumber teori:

\section{Studi Literatur}

Berfungsi sebagai pendukung dari penelitian yang akan dilaksanakan. Teori-teori yang digunakan bersumber dari buku, jurnal dan penelitianpenelitian sejenis yang dapat mendukung pemecahan masalah dalam penelitian yang dilakukan.

2. Dokumentasi (Documment)

Merupakan metode pengumpulan data dengan cara membaca, mencatat, mengutip, dan mengumpulkan data-data secara teoritis dari buku-buku dan internet sebagai landasan penyusunan penelitian [11]. Peneliti meminjam buku di perpustakaan, mencari data dari internet juga dilakukan untuk referensi laporan ini, dimana teori tersebut diletakkan pada landasan teori.

\subsection{Preprocessing E-mail}

Dalam penelitian ini pada tahap preprocessing, penulis tidak melakukan proses lemmatisasi fitur dan eliminasi stopwords karena dataset Lingspam yang digunakan sudah terlebih dahulu melakukan proses-proses tersebut. Pada tahap ini, input berupa dokumen e-mail akan diekstrak ke dalam bentuk kata/fitur. Dalam tahap ini juga dilakukan case folding dan menghilangkan karakter "-" karakter tertentu seperti tanda baca dan angka.

Subject
position
announcement
department
near
eastern
study
university
michigan
invite
application
tenure

track appointment arabic language culture assistant professor level authorize senior candidate consider

Gambar 3.4 Tokenisasi e-mail

\subsection{Ilustrasi Klasifikasi Email Menggunakan Naive Bayes}

Pada tahap ini akan dilakukan proses klasifikasi dimana akan didapatkan model klasifikasi berdasarkan input yang diberikan. Tabel 3.1 merupakan contoh dokumen latih dan uji yang kemudian akan dicari class yang paling cocok untuk dokumen uji (Dok 6).

Tabel 1 Tabel dokumen latih dan dokumen uji

\begin{tabular}{|l|c|l|l|}
\hline & Dok & \multicolumn{1}{|c|}{ Daftar kata dalam email } & \multicolumn{1}{|c|}{ class } \\
\hline Dokumen latih & 1 & Position, announcement, department & Ham \\
\hline & 2 & Job, announcement, department & Ham \\
\hline & 3 & Job, posting, announcement & Ham \\
\hline & 4 & Adult, nature, sexual & Spam \\
\hline & 5 & Social, security, number, criminal & Spam \\
\hline Dokumen uji & 6 & Tautologous, name, Mcnamara,level & $?$ \\
\hline
\end{tabular}

Untuk menyelesaikan kasus di atas, tahapan yang dilakukan adalah:

1. Buat tabe1 representasi dokumen latih seperti tampak pada Tabel 2.

Tabel 2 Tabel Representasi Dokumen Latih

\begin{tabular}{|l|c|c|c|c|c|}
\hline & Ham & Ham & Ham & Spam & Spam \\
\hline Position & 1 & & & & \\
\hline Announcement & 1 & 1 & 1 & & \\
\hline Deparment & 1 & 1 & & & \\
\hline Job & & 1 & 1 & & \\
\hline Posting & & & 1 & & \\
\hline Adult & & & & 1 & \\
\hline Nature & & & & 1 & \\
\hline Sexual & & & & 1 & \\
\hline Social & & & & & 1 \\
\hline Security & & & & & 1 \\
\hline
\end{tabular}




\begin{tabular}{|l|l|l|l|l|l|}
\hline Number & & & & & 1 \\
\hline Criminal & & & & & 1 \\
\hline Tautologous & & & & & \\
\hline Name & & & & & \\
\hline Mcnamara & & & & & \\
\hline Level & & & & & \\
\hline
\end{tabular}

Pada model multinomial, kata-kata yang muncul berulang diikutsertakan di dalam perhitungan probabilitas. Pada Tabel 3.2, kalimat pada Dok 1 yaitu "Position, announcement, department" akan direpresentasikan dengan cara menghitung frekuensi kemunculan kata "Position", yaitu 1 kali, kata "Announcement dan Department" muncul 1 kali, dan kata-kata lain memiliki frekuensi kemunculan nol.

2. Hitung prior probability dari dokumen latih. Merujuk pada Tabel 3.1 maka dengan menggunakan rumus pada Persamaan (2.5), diperoleh hasil $\mathrm{P}($ ham $)=3 / 5=0,6$ dan $\mathrm{P}($ spam $)=$ $2 / 5=0,4$

3. Hitung conditional probability menggunakan Persamaan (2.6).

Detail perhitungan conditional probability adalah : $\mathrm{P}($ position $\mid$ ham $)=\mathrm{P}($ posting $\mid$ ham $)=(1+1) /(9+16)$ $=0,088$

$\mathrm{P}($ announcement $\mid$ ham $)=(3+1) /(9+16)=0,16$

$\mathrm{P}($ department $\mid$ ham $)=\mathrm{P}($ job $\mid$ ham $)=(2+1) /(9+16)$

$=0,12$

$\mathrm{P}($ adult $\mid$ ham $)=\mathrm{P}($ nature $\mid$ ham $)=\mathrm{P}($ sexual $\mid$ ham $)=$ $\mathrm{P}($ social $\mid$ ham $)=\mathrm{P}($ sevurity $\mid$ ham $)=\mathrm{P}($ number $\mid$ ham $)$ $=\mathrm{P}($ criminal $\mid$ ham $)=\mathrm{P}($ tautologous $\mid$ ham $)=$ $\mathrm{P}($ name $\mid$ ham $)=\mathrm{P}($ mcnamara $\mid$ ham $)=\mathrm{P}($ level $\mid$ ham $)$

$=(0+1) /(9+16)=0,04$

$\mathrm{P}($ position $\mid$ spam $)=\mathrm{P}($ posting $\mid$ spam $)=$

$\mathrm{P}($ announcement $\mid$ spam $)=\mathrm{P}($ department $\mid$ spam $)=$

$\mathrm{P}($ job $\mid$ spam $)=\mathrm{P}($ tautologous $\mid$ spam $)=$

$\mathrm{P}($ name $\mid$ spam $)=\mathrm{P}($ menamara $\mid$ spam $)=$

$\mathrm{P}($ level $\mid$ spam $)=(0+1) /(7+16)=0,043$

$\mathrm{P}($ adult $\mid$ spam $)=\mathrm{P}($ nature $\mid$ spam $)=\mathrm{P}($ sexual $\mid$ spam $)$

$=\mathrm{P}($ social $\mid$ spam $)=\mathrm{P}($ sevurity $\mid$ spam $)=$

$\mathrm{P}($ number $\mid$ spam $)=\mathrm{P}($ criminal $\mid$ spam $)=$

$(1+1) /(7+16)=0,086$

4. Hitung score dari setiap class pada dokumen uji menggunakan Persamaan (2.2).

Score $($ ham $)=\mathrm{P}($ ham $) \times \mathrm{P}($ tautologous ham $) \mathrm{x}$ $\mathrm{P}($ name|ham $) \times \mathrm{P}($ monamara|ham $) \times \mathrm{P}($ level|ham $)$ $=(3 / 5) \times(0,04) 4=0,096$

Sedangkan score untuk class "spam" adalah: Score $($ spam $)=\mathrm{P}($ spam $) \times \mathrm{P}($ tautologous $\mid$ spam $) \mathrm{x}$ $\mathrm{P}($ name $\mid$ spam $) \times \mathrm{P}($ monamara|spam $) \mathrm{x}$ $\mathrm{P}($ level $\mid$ spam $)=(2 / 5) \times(0,043) 4=0,0688$
Prediksi class dokumen uji dengan cara memilih class yang memiliki skor terbesar. Dengan menggunakan Persamaan (2.3) tampak bahwa Ham > Spam, maka Dok 6 masuk dalam class "Ham".

\section{Hasil Dan Pembahasan}

\subsubsection{Implementasi Perangkat Lunak}

Implementasi dari metode naive bayes yang diterapkan pada dreamweaver dapat dilihat sebagai berikut:

\subsubsection{Tampilan Awal}

Desain fisiknya dapat dilihat pada Gambar 4.1
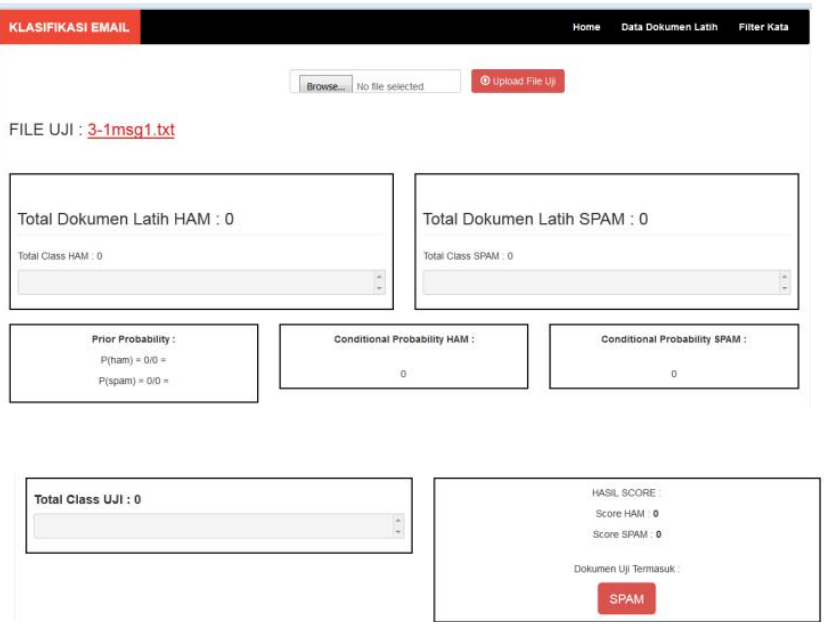

Gambar 4.1 Tampilan Awal

Pada sistem ini ada 3 buah menu bar yaitu, menu home, menu data dokumen latih dan menu filter kata. Pada menu home terdapat button browse untuk memilih file yang akan diuji lalu tekan button upload untuk mengupload file ujinya, dengan nama file (contoh : 3-1msg1.txt).

\subsubsection{Menu Data Dokumen Latih}

Tampilan menu dokumen latih dapat diliha pada gambar 4.2 berikut ini.

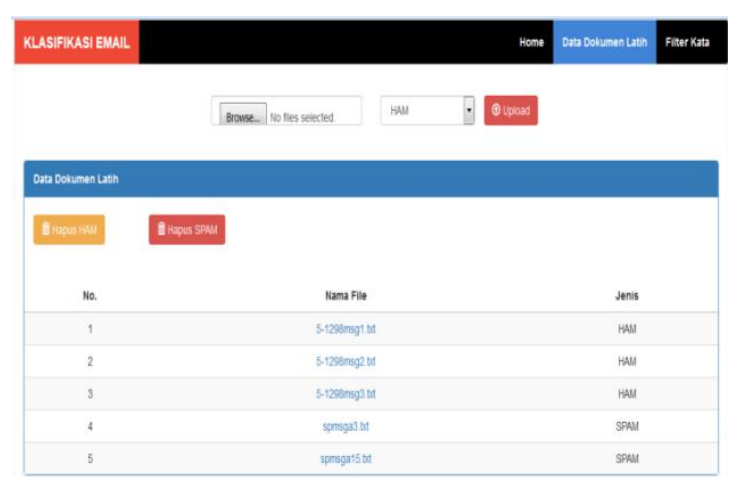

Gambar 4.2 Menu Data Dokumen Latih 
Pada menu data dokumen latih diatas berfungsi untuk mengupload file ham dan file spam sebagai dokumen latih, dengan cara klik browse pilih file yang akan di upload lalu klik button upload (sebagai contoh terlampir 3 file ham dan 2 file spam), kemudian ada button hapus ham dan hapus spam untuk menghapus file yang sudah di upload.

\subsubsection{Menu Filter Kata}

Kemudian di menu filter kata terdapat kolom untuk menginputkan kata kata yang memiliki frekuensi kemunculan yang tinggi dalam dokumen tetapi tidak memiliki nilai informasi yang tinggi (contoh : the, and, a, of, in, is, that, dll), seperti pada Gambar 4.3 dibawah ini.

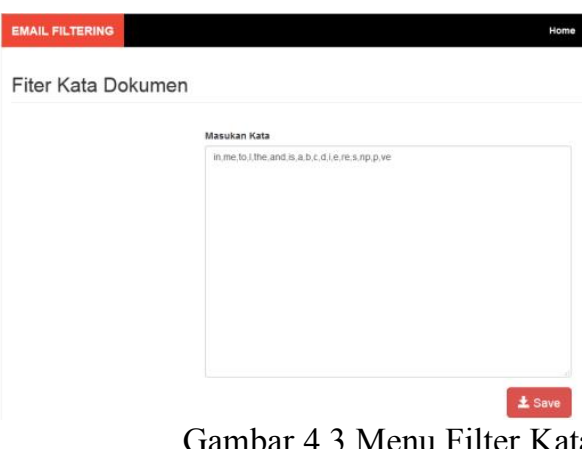

\subsubsection{Menu Home}

Pada menu home terdapat kotak bagian total dokumen latih ham dan kotak bagian total dokumen latih spam yang berfungsi untuk melihat total class/kata yang sering muncul pada 3 file ham dan 2 file spam yang di upload seperti gambar 4.4 ini.

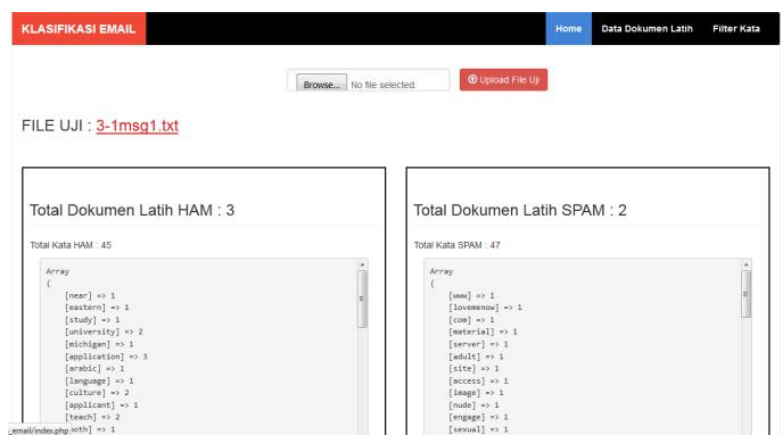

Gambar4.4 Class dokumen ham \& spam

Lalu pada gambar 4.5Maksudnya, kata near muncul paling sedikit 2 kali pada 1 file tertentu, kata application muncul paling sedikit 2 kali pada 3 file tertentu, kata culture muncul paling sedikit 2 kali pada 2 file tertentu.

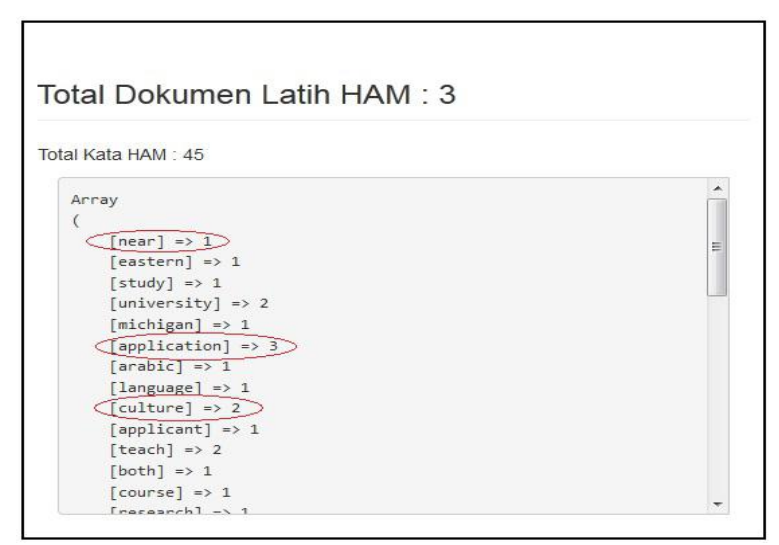

Gambar 4.5 Class Dokumen Latih

Dari gambar 4.6 di bawah ini contoh $\mathbf{P}(\mathbf{h a m})=\mathbf{3} / \mathbf{5}$ $=\mathbf{0 , 6}$, dimana 3 adalah dokumen latih yang berada di class ham, 5 adalah jumlah total dokumen latih, begitu juga dengan class spam.

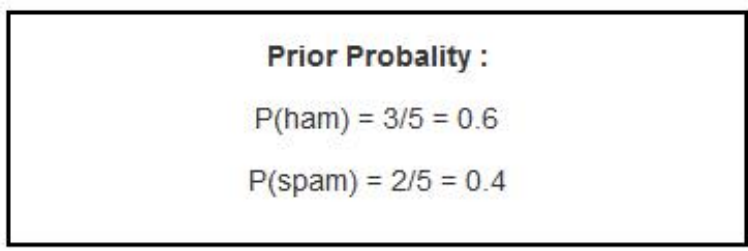

\section{Gambar 4.6 Prior Probability}

Conditional probability yaitu untuk menghitung kata dari setiap class untuk menentukan nilai yang digunakan dalam dokumen uji nantinya. Dalam contoh ini nilai yang digunakan adalah 0.007874 untuk class ham dan 0.007463 untuk class spam.
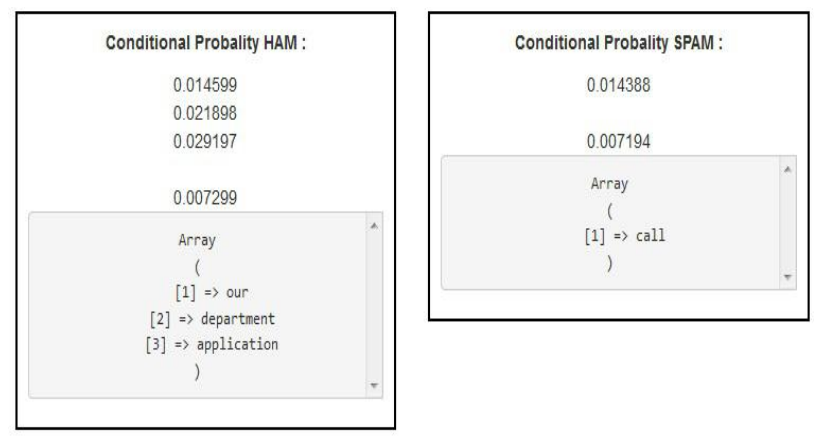

Gambar 4.7 Conditional Probability

$$
\mathrm{P}=\frac{T_{\mathrm{n}}+1}{T_{C}+\mathrm{B}^{\prime}}
$$

$T_{\mathrm{n}}=$ jumlah kemunculan kata dalam dokumen latih pada class.

$T_{C}=$ jumlah kata yang muncul dalam setiap class.

$\mathrm{B}^{\prime}=$ total jumlah kata pada class. 


\section{Perhitungan HAM}

1. $\mathrm{P}=\frac{1+1}{45+92}=0,014599$

2. $\mathrm{P}=\frac{2+1}{45+92}=0,021898$

3. $\mathrm{P}=\frac{3+1}{45+92}=0,029197$

4. $\mathrm{P}=\frac{0+1}{45+92}=0,007299$

\section{Perhitungan SPAM}

1. $\mathrm{P}=\frac{1+1}{47+92}=0,014388$

2. $\mathrm{P}=\frac{0+1}{47+92}=0,007194$

Maka yang digunakan adalah nilai nomer 4 untuk ham dan nilai nomer 2 untuk spam karena, kata/fitur yang terdapat pada dokumen uji tidak ada yang sama dengan di dokumen latih.

Pada dokumen uji ada 12 kata yang paling sering muncul, kata mcnamara, name, toutologous, value muncul sebanyak 3 kali, kata construction, reduplication dan sense muncul sebanyak 2 kali dan lain-lain. 12 kata ini yang nantinya akan di kalikan dengan nilai conditional probability.

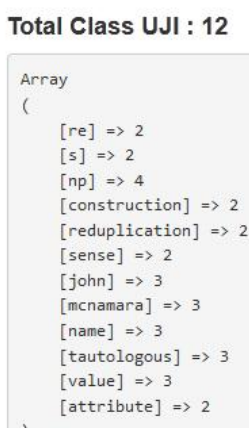

Gambar 4.8 Class Dokumen Uji

Hasil score didapat dari prior probability dikali (conditional probability dikali jumlah kata dokumen uji).

HAM : 0,6 x $(0,007299) 12=0,0525528$

$$
\text { SPAM : } 0,4 \times(0,007194) 12=0,0345312
$$

Jadi, hasilnya jika score ham lebih besar daripada score spam maka, dokumen uji tersebut masuk pada class Ham.

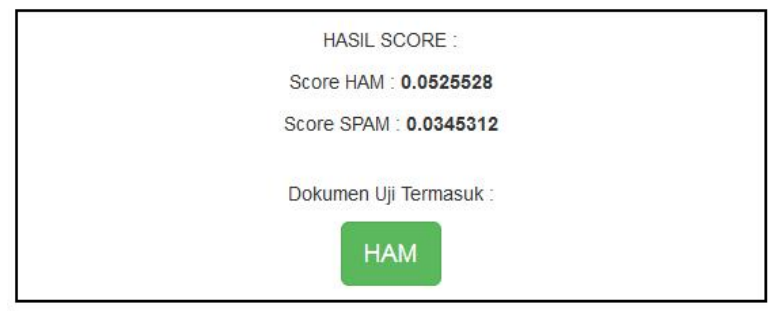

Gambar 4.9 Hasil Score

Dari contoh percobaan diatas dimana dokumen yang digunakan adalah 5 dokumen, dengan 3 dokumen Ham (5-1298msg1.txt, 5-1298msg2.txt dan 51298msg3.txt) dan 2 dokumen Spam (spmsga3.txt, dan spmsga15.txt) didapat nilai akurasi :

$$
\begin{aligned}
& \text { Akurasi } \\
& =\frac{\text { jumlahprediksibenar }}{\text { jumlahdatauji }} \times 100 \%
\end{aligned}
$$

$$
\begin{aligned}
& \text { Akurasi }=\frac{3}{5} \times 100 \% \\
& \text { Akurasi }=0,6 \times 100 \% \\
& \text { Akurasi }=60 \%
\end{aligned}
$$

\section{Kesimpulan}

Kesimpulan dari hasil penelitian yang telah dilakukan adalah sebagai berikut:

1. Metode Nä̈ve Bayes Classifier dapat digunakan untuk melakukan klasifikasi email spam berbahasa inggris.

2. Jumlah data latih sangat berpengaruh dalam proses klasifikasi, karena jika kata yang sering muncul pada setiap class nya lebih banyak dan dokumen latih pada setiap class nya juga lebih banyak maka akan meningkatkan nilai akurasi pada class tersebut.

3. Hasil klasifikasi tergantung dari kata yang ada pada data latih.

\section{Saran}

1. Diperlukan adanya penelitian lanjutan pada nä̈ve bayes classifier khususnya dalam hal menangani dataset yang memiliki jumlah data yang tidak seimbang di dalam class (unbalanced data) serta penggunaan dataset berbahasa indonesia agar lebih mudah digunakan oleh pembaca.

2. Aplikasi dapat dikembangkan lebih lanjut sehingga mampu melakukan analisis terhadap body email bertipe html atau mime dan attachment yang dianalisa dari contentnya 


\section{Daftar Pustaka}

[1] M. Sharma, "A Survey of Email Spam Filtering Methods," vol. 7, pp. 14-21, 2018.

[2] B. Kurniawan, S. Effendi, and O. S. Sitompul, "Klasifikasi Konten Berita Dengan Metode Text Mining," J. Dunia Teknol. Inf., vol. 1, no. 1, pp. 14-19, 2012, [Online]. Available: http://download.portalgaruda.org/article.php?article $=58993 \& \mathrm{val}=4123$.

[3] O. Saad, A. Darwish, and R. Faraj, "A survey of machine learning techniques for Spam filtering," $J$. Comput. Sci., vol. 12, no. 2, pp. 66-73, 2012.

[4] M. Bakri, "Penerapan Data Mining untuk Clustering Kualitas Batu Bara dalam Proses Pembakaran di PLTU Sebalang Menggunakan Metode K-Means," J. Teknoinfo, vol. 11, no. 1, p. 6, 2017, doi: 10.33365/jti.v11i1.3.

[5] A. S. Rajput, V. Athavale, and S. Mittal, "Intelligent model for classification of SPAM and HAM," Int. J. Innov. Technol. Explor. Eng., vol. 8, no. 6, pp. 773-777, 2019.

[6] A. Hamzah, "Klasifikasi Teks Dengan Naïve Bayes Classifier (NBC) Untuk Pengelompokan Teks
Berita Dan Abstract Akademis," Pros. Semin. Nas. Apl. Sains Teknol. Periode III, no. 2011, pp. 269277, 2012, doi: 1979-911X.

[7] R. Kaur and P. Luthra, "Load Balancing in Cloud Computing," pp. 1-8, 2014.

[8] D. Damayanti and H. Sulistiani, "Sistem Informasi Pembayaran Biaya Sekolah Pada SD Ar-Raudah Bandar Lampung," J. Teknoinfo, vol. 11, no. 2, p. 25, 2017, doi: 10.33365/jti.v11i2.23.

[9] A. S. Patil and B. V. Pawar, "Automated classification of web sites using Naive Bayesian algorithm," Lect. Notes Eng. Comput. Sci., vol. 2195, pp. 519-523, 2012.

[11] Jupriyadi, J. (2018). Implementasi Seleksi Fitur Menggunakan Algoritma Fvbrm Untuk Klasifikasi Serangan Pada Intrusion Detection System (Ids). Prosiding Semnastek.

[12] E. R. Susanto and A. S. Puspaningrum, "Model Prioritas Program Pemerataan Ipm Di Provinsi Lampung Menggunakan Metode Analytic Hierarchy Process," J. Teknoinfo, vol. 14, no. 1, p. 9, 2020, doi: 10.33365/jti.v14i1.543. 